Article

\title{
Susceptibility of Tribolium castaneum (Coleoptera: Tenebrionidae) to the Fumigation of Two Essential Satureja Oils: Optimization and Modeling
}

\author{
Asgar Ebadollahi 1,*(D), Ebrahim Taghinezhad ${ }^{1}$, William N. Setzer ${ }^{2,3} \mathbb{D}$ and Guangnan Chen ${ }^{4, *(\mathbb{D})}$ \\ 1 Moghan College of Agriculture and Natural Resources, University of Mohaghegh Ardabili, \\ Ardabil 56199-36514, Iran; taghinezhad@uma.ac.ir \\ 2 Department of Chemistry, University of Alabama in Huntsville, Huntsville, AL 35899, USA; setzerw@uah.edu \\ 3 Aromatic Plant Research Center, 230 N 1200 E, Suite 100, Lehi, UT 84043, USA \\ 4 Faculty of Health, Engineering and Sciences, University of Southern Queensland, \\ Toowoomba, QLD 4350, Australia \\ * Correspondence: ebadollahi@uma.ac.ir (A.E.); Guangnan.Chen@usq.edu.au (G.C.)
}

\section{check for}

updates

Citation: Ebadollahi, A.;

Taghinezhad, E.; Setzer, W.N.; Chen,

G. Susceptibility of Tribolium

castaneum (Coleoptera:

Tenebrionidae) to the Fumigation of

Two Essential Satureja Oils:

Optimization and Modeling. Processes

2021, 9, 1243. https://doi.org/

$10.3390 /$ pr9071243

Academic Editor:

David Fernández-Calviño

Received: 18 June 2021

Accepted: 13 July 2021

Published: 19 July 2021

Publisher's Note: MDPI stays neutral with regard to jurisdictional claims in published maps and institutional affiliations.

Copyright: (c) 2021 by the authors. Licensee MDPI, Basel, Switzerland. This article is an open access article distributed under the terms and conditions of the Creative Commons Attribution (CC BY) license (https:// creativecommons.org/licenses/by/ $4.0 /)$.

\begin{abstract}
Due to the numerous side effects of synthetic pesticides, including environmental pollution, threats to human health, harmful effects on non-target organisms and pest resistance, the use of alternative healthy, available and efficient agents in pest management strategies is necessary. In this paper, the susceptibility of the cosmopolitan, polyphagous, stored-product pest Tribolium castaneum (red flour beetle) to the fumigation of the essential oils of two important medicinal and food additive plants, Satureja hortensis and S. intermedia, was investigated. The insecticidal properties of the essential oils were modeled and optimized using response surface methodology. It was found that a maximum significant mortality of $94.72 \%$ and $92.97 \%$ could be achieved within $72 \mathrm{~h}$ with the applications of $55.15 \mu \mathrm{L} / \mathrm{L}$ of $S$. hortensis (with the linear model) and $58.82 \mu \mathrm{L} / \mathrm{L}$ of $S$. intermedia (with the quadratic model), respectively. There were insecticidal terpenes and phenylpropanoids in both essential oils, including thymol (50.8\%), carvacrol (11.2\%) and $p$-cymene $(13.4 \%)$, in the S. intermedia and estragole $(68.0 \%)$ and methyl eugenol (5.6\%) in the S. hortensis. It was suggested that the essential oils of $S$. hortensis and $S$. intermedia could be offered as promising pesticidal agents against $T$. castaneum for further studies in the management of such pests instead of detrimental synthetic pesticides.
\end{abstract}

Keywords: biorational pesticides; chemical profile; fumigant toxicity; modeling; optimization; S. hortensis; S. intermedia

\section{Introduction}

The globally distributed insect pest, the red flour beetle Tribolium castaneum Herbst (Coleoptera: Tenebrionidae), attacks several stored grain products such as beans, cereals, chocolate, flour, meal, nuts, seeds and spices [1]. The adults of T. castaneum are long-lived; they can live for up to three years [2]. In addition to qualitative nutritional damage, contaminated products also have reduced quality due to the creation of an unpleasant odor by the secretion of benzoquinone compounds from abdominal glands and remains of various molting stages and cadavers [3]. Furthermore, T. castaneum can transmit phytopathogenic microbial agents such as Aspergillus, Pseudomonas and Staphylococcus to infested storage products [4,5]. Bosly and Kawanna [6] demonstrated that T. castaneum can actually carry and distribute some Aspergillus species, particularly A. flavus, the main producer of carcinogenic aflatoxins in agricultural products [7], in stored flour.

Although the use of synthetic pesticides is the principal approach in pest management, the widespread use of these compounds has resulted in numerous side effects, such as environmental contaminations, the accumulation of hazardous residues in food and high toxicity to non-target organisms [8-10]. In addition, the resistance of pests to frequently used chemical pesticides is increasing. For example, the resistance of T. castaneum to 
phosphine, as one of the commonly used fumigants against stored grain insect pests, was reported [11-13]. Therefore, the introduction of low-risk, available and effective pesticides is essential to alternate with synthetic chemicals in the management of such pests.

The effectiveness of plant-derived essential oils in insect pest control has been demonstrated in numerous studies in recent years [14,15]. Along with the prospective insecticidal effects of essential oils on insect pests from various species, genera, families and orders, their biodegradable nature, safety compared to synthetic chemicals and multiple modes of action in targeted pests indicate that they can be suitable alternatives to detrimental chemical pesticides [16,17]. In fact, the volatile oils obtained from different species of the Satureja genus were enriched with terpenes such as 1,8-cineole, $\gamma$-terpinene, thymol and $\beta$-caryophyllene, which were grouped into four primary classifications: monoterpene hydrocarbons, oxygenated monoterpenes, sesquiterpene hydrocarbons and oxygenated sesquiterpenes [18-20]. Promising insecticidal effects of Satureja essential oils against insect pests of storage products were also reported. These included, for example, insecticidal activities of $S$. bachtiarica Bung and S. khuzestanica Jamzad essential oils against $T$. castaneum [21], S. hortensis L. essential oil against the bean weevil (Bruchus dentipes (Baudi)) [19] and the cowpea weevil (Callosobruchus maculatus (Fabricius)) [22] and S. spicigera Boiss essential oil against the granary weevil (Sitophilus granarius (L.)) [23] and the maize weevil (Sitophilus zeamais Motschulsky) [24].

Response surface methodology (RSM) is a set of mathematical and statistical tools for the optimization of independent factors and modeling of dependent factors [25]. The optimization of agricultural and chemical processes requires the simultaneous optimization of several objective functions [26]. Therefore, RSM has been used in numerous agricultural and pharmacological fields [27-30]. For example, RSM was used to find mathematical models and optimized conditions for the toxicity of Eucalyptus globulus Labill and Teucrium polium L. essential oils against $T$. castaneum [31,32].

Given the importance of using natural and low-risk compounds in pest management, the main purpose of the present study is to investigate the possibility of using S. intermedia C. A. Mey and S. hortensis L. essential oils in the control of T. castaneum. The insecticidal properties of essential oils are modeled and optimized using response surface methodology. Due to changes in essential oil composition under different environmental and geographical conditions [18], the chemical profiles of the S. intermedia and S. hortensis essential oils were also assessed.

\section{Materials and Methods}

\subsection{Plant Materials and Extraction of the Essential Oils}

S. intermedia was gathered from its wild populations in the Heiran regions in Ardebil Province, Iran $\left(38^{\circ} 230^{\prime} \mathrm{N}, 48^{\circ} 350^{\prime} \mathrm{E}\right.$ and an elevation of $\left.910 \mathrm{~m}\right)$. S. hortensis was collected from Parsabad, Ardebil Province, Iran ( $39^{\circ} 38^{\prime} \mathrm{N}, 47^{\circ} 52^{\prime} \mathrm{E}$ and an elevation of $\left.52 \mathrm{~m}\right)$. The Satureja species were identified based on the work of Jamzad [33]. The fresh leaves and flowers of S. intermedia and S. hortensis were used for essential oil extraction. All specimens were allowed to dry in the shade over a 10-day period. For each plant sample, $100 \mathrm{~g}$ of plant material was added to a 2-L flask of the Clevenger apparatus and subjected to $3 \mathrm{~h}$ hydrodistillation. The extracted essential oils were then individually poured into glass vials, covered with aluminum foil, dried over anhydrous $\mathrm{Na}_{2} \mathrm{SO}_{4}$ and kept in the refrigerator at $4{ }^{\circ} \mathrm{C}$ until use.

\subsection{Chemical Profiles of the Essential Oils}

The Satureja essential oils were analyzed by gas chromatography-mass spectrometry using an Agilent 7890B GC with an Agilent 5977A mass selective detector (MSD), operated in the EI mode (electron energy $=70 \mathrm{eV}$, scan range $=50-550 \mathrm{amu}$ and scan rate $=3.99 \mathrm{scans} / \mathrm{s}$ ). The GC column was an HP-5ms fused silica capillary column ( $30 \mathrm{~m}$ in length, $0.25 \mathrm{~mm}$ internal diameter, (5\% phenyl)-polymethylsiloxane stationary phase and $0.25 \mu \mathrm{m}$ film thickness). Helium was the carrier gas, with a $52.8 \mathrm{kPa}$ column head pressure and $1.0 \mathrm{~mL} / \mathrm{min}$ flow 
rate. The inlet temperature was $200{ }^{\circ} \mathrm{C}$, and the interface temperature was $280^{\circ} \mathrm{C}$. The GC oven temperature was programed to hold for $1 \mathrm{~min}$ at $50{ }^{\circ} \mathrm{C}$ and then increase at a rate of $6{ }^{\circ} \mathrm{C} / \mathrm{min}$ to a final temperature of $290{ }^{\circ} \mathrm{C}$, with a total run time of $50 \mathrm{~min}$. A $10 \% \mathrm{w} / \mathrm{v}$ solution of the sample in methanol was prepared, and $1 \mu \mathrm{L}$ was injected using a 100:1 split ratio. Identification of the oil components was based on their retention indices, determined by reference to a homologous series of $n$-alkanes and by comparison of their mass spectral fragmentation patterns with those reported in the databases [34-36].

\subsection{Insect Rearing}

Adult T. castaneum specimens were collected from contaminated wheat grains in warehouses in Parsabad, Ardabil Province, Iran $\left(39^{\circ} 38^{\prime} \mathrm{N}, 47^{\circ} 52^{\prime} \mathrm{E}\right.$ and an elevation of $52 \mathrm{~m})$. The adults were reared on wheat grains in cylindrical glass containers $(720 \mathrm{~mL})$ covered by a fine mesh cloth for ventilation. Contaminated grains were kept in the incubator at $27 \pm 2{ }^{\circ} \mathrm{C}$ and $60 \pm 5 \% \mathrm{RH}$ in the dark. Newly emerged adult insects 1-10 days old were selected for the bioassays.

\subsection{Fumigant Toxicity}

A series of concentrations from 20.59 to $58.82 \mu \mathrm{L} / \mathrm{L}$ and from 21.00 to $55.15 \mu \mathrm{L} / \mathrm{L}$ was selected to assess the fumigant toxicity of $S$. intermedia and $S$. hortensis essential oils, respectively. Filter papers (Whatman No. 1; $2 \times 2 \mathrm{~cm}$ ) separately treated with the concentrations of the essential oils were glued to the inner surface of the screw caps of fumigant glass containers $(340 \mathrm{~mL})$. Twenty unsexed adults (1-10 days old) were transferred to containers before screwing their caps. Then, the caps were sealed to be impermeable to air with parafilm. The bioassay was repeated four times, and in the control groups, all steps were performed except for adding essential oils. The fumigant containers were kept in an incubator with $27 \pm 2{ }^{\circ} \mathrm{C}$ and $60 \pm 5 \% \mathrm{RH}$, and insect mortality was recorded after 24,48 and $72 \mathrm{~h}$ of exposure. The mortality in the control groups was corrected by the following formula: $P \mathrm{t}=\left[\left(P_{\mathrm{o}}-P_{\mathrm{c}}\right) /\left(100-P_{\mathrm{c}}\right)\right] \times 100$, in which $P_{\mathrm{t}}$ is the corrected mortality percentage, $P o$ is the mortality of the insects treated by essential oil concentrations and $P_{C}$ is the mortality of the insects in the control groups [37].

\subsection{Modeling and Optimization by RSM}

Using RSM under the historical data design by the statistical software Design Expert 8.0.6 (Stat-Ease, Inc., Minneapolis, MN, USA), various concentrations of essential oils were analyzed in five levels, with the exposure times in three levels as the independent variables and with the mortality of T. castaneum as the dependent variable.

Multiple linear regression analysis for the interactions of the independent and dependent variables was used to achieve the statistically appropriate mathematical model in the following second-order polynomial equation [38]:

$$
y=\beta o+\sum_{i=1}^{k} \beta_{i} X_{i}+\sum_{i=1}^{k} \beta_{j} X_{j}+\sum_{i=1}^{k} \sum_{j=1}^{k} \beta_{i j} X_{i} X_{j}+\sum_{i=1}^{k} \beta_{j j} X_{j}^{2}
$$

where $y$ is the mortality of T. castaneum (dependent variable), $X_{i}$ and $X_{j}$ are the exposure times and essential oil concentrations, respectively (independent variables), $k$ is a number of independent variables (2), $\beta_{o}$ is the intercept of the model, $\beta_{i}$ and $\beta_{j}$ are the coefficients of the linear parameters and $\beta_{i j}$ specifies the quadratic parameter coefficient. The statistical relationship between the independent and dependent variables was evaluated by the correlation coefficient of determination $\left(R^{2}\right)$, adjusted $R^{2}$ and predicted $R^{2}$. Optimization of the insect pest mortality caused by the fumigation of $S$. intermedia and $S$. hortensis essential oils was performed to the maximum desirability using Design Expert software with RSM. The statistical significance of the independent variables on the response variables was examined at a 95\% confidence level $(p<0.05)$, and only the variables with a significant effect on the response variable were used in the proposed regression equation. 


\section{Results}

The results of the GC-MS analyses of the essential oils of S. intermedia and S. hortensis are presented in Table 1. It can be seen that the essential oil of S. intermedia was rich in the phenolic monoterpenes thymol (50.8\%) and carvacrol (11.2\%) along with monoterpenes p-cymene $(13.4 \%)$ and 1,8-cineole $(4.3 \%)$. The essential oil of S. hortensis, on the other hand, was dominated by phenylpropanoids, especially estragole $(68.0 \%)$ as well as methyl eugenol (5.6\%) and (E)-p-methoxycinnamaldehyde (4.4\%) (Table 1 and Figure 1).

Table 1. Chemical profiles of the essential oils isolated from the aerial parts of S. intermedia and S. hortensis.

\begin{tabular}{|c|c|c|c|c|}
\hline \multirow{2}{*}{ RIcalc } & \multirow{2}{*}{ RIdb } & \multirow{2}{*}{ Compound } & \multicolumn{2}{|c|}{ Percent Composition } \\
\hline & & & S. intermedia & S. hortensis \\
\hline 933 & 933 & $\alpha$-Pinene & 1.3 & 1.3 \\
\hline 978 & 982 & 1-Octen-3-ol & 0.9 & - \\
\hline 1005 & 999 & 3-Octanol & 0.4 & - \\
\hline 1025 & 1024 & Limonene & - & 0.9 \\
\hline 1027 & 1025 & p-Cymene & 13.4 & - \\
\hline 1031 & 1032 & 1,8-Cineole & 4.3 & - \\
\hline 1031 & 1032 & (Z)- $\beta$-Ocimene & - & 1.2 \\
\hline 1048 & 1044 & (E)- $\beta$-Ocimene & - & 0.9 \\
\hline 1054 & 1057 & $\gamma$-Terpinene & 1.0 & - \\
\hline 1097 & 1091 & Rosefuran & - & 0.2 \\
\hline 1101 & 1101 & Linalool & 0.2 & 0.2 \\
\hline 1105 & 1102 & 6-Methylhepta-3,5-dien-2-one & - & 0.2 \\
\hline 1129 & 1127 & allo-Ocimene & - & 1.3 \\
\hline 1137 & 1138 & cis-p-Mentha-2,8-dien-1-ol & - & 0.2 \\
\hline 1143 & 1142 & (E)-Myroxide & - & 0.2 \\
\hline 1149 & 1145 & trans-Verbenol & - & 0.1 \\
\hline 1174 & 1171 & p-Mentha-1,5-dien-8-ol & - & 0.2 \\
\hline 1174 & 1173 & Borneol & 0.2 & 0.1 \\
\hline 1181 & 1180 & Terpinen-4-ol & 0.7 & 0.1 \\
\hline 1203 & 1201 & Estragole (=Methyl chavicol) & - & 68.0 \\
\hline 1211 & 1211 & $\beta-$-Cyclocitral & - & 0.4 \\
\hline 1223 & 1223 & trans-Carveol & - & 0.1 \\
\hline 1237 & 1239 & Thymyl methyl ether & 1.8 & - \\
\hline 1248 & 1244 & Carvacryl methy ether & 3.1 & - \\
\hline 1256 & 1252 & Chavicol & - & 0.2 \\
\hline 1259 & 1257 & p-Anisaldehyde & - & 0.5 \\
\hline 1288 & 1289 & Thymol & 50.8 & 0.3 \\
\hline 1296 & 1298 & Carvacrol & 11.2 & 0.8 \\
\hline 1361 & 1356 & Eugenol & - & 0.1 \\
\hline 1362 & 1365 & Carvacryl acetate & 0.1 & - \\
\hline 1407 & 1405 & Methyl eugenol & - & 5.6 \\
\hline 1424 & 1424 & (E)- $\beta$-Caryophyllene & 1.1 & - \\
\hline 1478 & 1478 & $\gamma$-Muurolene & 0.2 & - \\
\hline 1490 & 1490 & (E)- $\beta$-Ionone & - & 0.3 \\
\hline 1497 & 1491 & Viridiflorene & 0.4 & - \\
\hline 1500 & 1500 & $\alpha$-Muurolene & 0.1 & - \\
\hline 1508 & 1508 & $\beta$-Bisabolene & 0.9 & - \\
\hline 1516 & 1514 & $\gamma$-Cadinene & 0.2 & - \\
\hline 1524 & 1518 & $\delta$-Cadinene & 0.4 & - \\
\hline 1540 & 1541 & (E)- $\alpha$-Bisabolene & 0.1 & - \\
\hline 1544 & 1544 & $\alpha$-Calacorene & 0.1 & - \\
\hline 1552 & 1554 & Thymohydroquinone & 0.4 & - \\
\hline 1575 & 1567 & (E)-p-Methoxycinnamaldehyde & - & 4.4 \\
\hline 1576 & 1576 & Spathulenol & 1.0 & 0.5 \\
\hline 1587 & 1583 & allo-Spathulenol & - & 3.5 \\
\hline 1589 & 1587 & Caryophyllene oxide & 0.8 & 0.8 \\
\hline 1611 & 1614 & 1,10-di-epi-Cubenol & - & 0.4 \\
\hline 1613 & 1613 & Humulene epoxide II & 0.1 & - \\
\hline
\end{tabular}


Table 1. Cont.

\begin{tabular}{|c|c|c|c|c|}
\hline \multirow{2}{*}{ RIcalc } & \multirow{2}{*}{ RIdb } & \multirow{2}{*}{ Compound } & \multicolumn{2}{|c|}{ Percent Composition } \\
\hline & & & S. intermedia & S. hortensis \\
\hline 1629 & 1631 & 1-epi-Cubenol & $\operatorname{tr}$ & - \\
\hline 1635 & 1638 & cis-Cadin-4-en-7-ol & 0.1 & - \\
\hline 1636 & 1629 & iso-Spathulenol & - & 0.2 \\
\hline 1639 & 1636 & Caryophylla-4(12),8(13)-dien-5 $\beta$-ol & 0.1 & - \\
\hline 1641 & 1640 & $\tau$-Cadinol & 0.1 & - \\
\hline 1646 & 1645 & $\alpha$-Muurolol (= $\delta$-Cadinol) & $\operatorname{tr}$ & - \\
\hline 1655 & 1655 & $\alpha$-Cadinol & 0.1 & - \\
\hline 1658 & 1656 & 14-Hydroxy-9-epi-(Z)-caryophyllene & 0.1 & - \\
\hline 1667 & 1668 & ar-Turmerone & 0.5 & 0.2 \\
\hline 1667 & 1668 & $\beta$-Turmerone & $\operatorname{tr}$ & - \\
\hline 1672 & 1666 & 14-Hydroxy-9-epi-(E)-caryophyllene & 0.2 & - \\
\hline 1675 & 1677 & Cadalene & $\operatorname{tr}$ & - \\
\hline 1681 & 1679 & epi- $\alpha$-Bisabolol & $\operatorname{tr}$ & - \\
\hline 1687 & 1683 & Germacra-4(15),5,10(14)-trien-1 $\alpha$-ol & $\operatorname{tr}$ & - \\
\hline 1699 & 1701 & Curlone & 0.1 & - \\
\hline 1841 & 1841 & Phytone & 0.1 & 0.4 \\
\hline 1926 & 1925 & Methyl palmitate & - & 0.2 \\
\hline \multirow[t]{8}{*}{2109} & 2109 & Phytol & - & 1.2 \\
\hline & & Monoterpene hydrocarbons & 15.7 & 5.7 \\
\hline & & Oxygenated monoterpenoids & 72.8 & 2.8 \\
\hline & & Sesquiterpene hydrocarbons & 3.5 & 0.0 \\
\hline & & Oxygenated sesquiterpenoids & 3.1 & 5.6 \\
\hline & & Benzenoid aromatics & 0.0 & 78.7 \\
\hline & & Others & 1.4 & 2.3 \\
\hline & & Total identified & 96.4 & 95.0 \\
\hline
\end{tabular}

RIcalc $=$ Retention index, determined with respect to a homologous series of $n$-alkanes on an HP- 5 ms column; RIdb = Retention index from the databases.<smiles>Cc1ccc(C(C)C)cc1</smiles>

p-Cymene<smiles>C=CCc1ccc(OC)cc1</smiles>

Estragole<smiles>Cc1ccc(C(C)C)c(O)c1</smiles>

Thymol<smiles>C=CCc1ccc(OC)c(OC)c1</smiles>

Methyl eugenol<smiles>Cc1ccc(C(C)C)cc1O</smiles>

Carvacrol<smiles>COc1ccc(/C=C/C=O)cc1</smiles>

p-Methoxycinnamaldehyde

Figure 1. The structures of the major components in the essential oils of Satureja intermedia and S. hortensis.

Table 2 shows the results of the analysis of variance (ANOVA), which indicated that the mortality of $T$. castaneum adults was significantly affected by A (exposure time) and $\mathrm{B}$ (essential oil concentration) in the $S$. hortensis treatment and by $\mathrm{A}, \mathrm{B}$, and $\mathrm{B}^{2}$ in the $S$. intermedia treatment $(p<0.01)$. The lack-of-fit test for both essential oils was non-significant, demonstrating the validation of treatments (Table 2).

In Table 3, the fitting effect of different levels of the essential oil concentration and exposure time on the mortality amount is presented. The model's fitting was evaluated on the basis of the coefficient of determination $\left(R^{2}\right)$, adjusted $R^{2}$ and prediction $R^{2}$ as well as the coefficient of variation (CV). It can be seen that all the $R^{2}$ values were high $(>0.94)$, meaning that the response surface methodology models were suitable. Furthermore, the coefficient of variation for almost all parameters was below $8.4 \%$. This means that the results demonstrated good accuracy and precision with the reliability of experiments. As 
is shown in Table 3, it was found that the linear effects of the dependent variables on the mortality amount were significant $(p<0.05)$ under the essential oil of $S$. hortensis. The effect on the mortality value under the essential oil of $S$. intermedia was significant according to the quadratic equation $(p<0.05)$. The mortality was strongly influenced by the essential oil concentrations, based on the higher coefficient for B in the equation of Table 3.

Table 2. Results of analysis of variance for prediction of the fumigant toxicity of S. intermedia and S. hortensis essential oils against T. castaneum.

\begin{tabular}{|c|c|c|c|c|c|c|}
\hline Essential Oil & Source & Sum of Squares & df & Mean Square & F Value & $p$-Value \\
\hline \multirow{8}{*}{ S. intermedia } & Model & $21,460.07$ & 3 & 7153.36 & 287.26 & $<0.0001$ \\
\hline & A & 4305.62 & 1 & 4305.62 & 172.90 & $<0.0001$ \\
\hline & B & $16,798.40$ & 1 & $16,798.40$ & 674.58 & $<0.0001$ \\
\hline & $\mathrm{B}^{2}$ & 518.89 & 1 & 518.89 & 20.84 & $<0.0001$ \\
\hline & Residual & 1394.51 & 56 & 24.90 & & \\
\hline & Lack of Fit & 250.76 & 11 & 22.80 & 0.90 & $0.5504 \mathrm{NS}$ \\
\hline & Pure Error & 1143.75 & 45 & 25.42 & & \\
\hline & Model & $25,853.86$ & 2 & $12,926.93$ & 760.04 & $<0.0001$ \\
\hline \multirow{6}{*}{ S. hortensis } & A & 4622.50 & 1 & 4622.50 & 271.78 & $<0.0001$ \\
\hline & B & $21,231.36$ & 1 & $21,231.36$ & 1248.30 & $<0.0001$ \\
\hline & Residual & 969.47 & 57 & 17.01 & & \\
\hline & Lack of Fit & 231.97 & 12 & 19.33 & 1.18 & $0.3262 \mathrm{NS}$ \\
\hline & Pure Error & 737.50 & 45 & 16.39 & & \\
\hline & Cor Total & $26,823.33$ & 59 & & & \\
\hline
\end{tabular}

A: exposure time (h); B: essential oil concentrations ( $\mu \mathrm{L} / \mathrm{L})$; NS: non-significant.

Table 3. RSM modeling results for predicting the mortality percentage under different concentrations of essential oils and exposure times.

\begin{tabular}{cccccc}
\hline Essential Oil & Equation & $\mathbf{R}^{\mathbf{2}}$ Value & Adj $^{\mathbf{2}}$ & Pred R $^{\mathbf{2}}$ & C.V. (\%) $^{(\%)}$ \\
\hline S. intermedia & $-34.33772+0.43229 \mathrm{~A}+2.77692 \mathrm{~B}-0.019410 \mathrm{~B}^{2}$ & 0.9390 & 0.9357 & 0.9297 & 8.40 \\
S. hortensis & $-23.11885+0.44792 \mathrm{~A}+1.55199 \mathrm{~B}$ & 0.9639 & 0.9626 & 0.9600 & 7.59 \\
\hline
\end{tabular}

A: exposure time (h); B: essential oil concentrations $(\mu \mathrm{L} / \mathrm{L})$.

Figure 2 presents the effect of different concentrations of essential oils (in five levels) and exposure times (in three intervals) on the mortality of T. castaneum adults. It can be seen that the susceptibility or the mortality of the insect pest was increased by increasing the concentrations of both the essential oils and the exposure times. According to the color points in Figure 2, the mortality of T. castaneum was increased from $15 \%$ to $95 \%$ and from $20 \%$ to $100 \%$ by increasing the concentrations of the S. hortensis and S. intermedia essential oils from 21.00 to $55.15 \mu \mathrm{L} / \mathrm{L}$ and from 20.59 to $58.82 \mu \mathrm{L} / \mathrm{L}$, respectively, and the exposure times from 24 to $72 \mathrm{~h}$.

Plots of the residuals versus the predicted mortality of T. castaneum adults caused by the fumigation of S. intermedia and S. hortensis essential oils are shown in Figure 3. It can be seen that the introduced models for predicting T. castaneum mortality were accurate and consistent with the variation hypothesis.

The optimized conditions for the significant maximum mortality of T. castaneum adults treated by the essential oils of $S$. intermedia and $S$. hortensis after different exposure times are shown in Table 4 . After $72 \mathrm{~h}$ of exposure time, the maximum mortality of the pest $(92.973 \%)$ may be achieved with $58.820 \mu \mathrm{L} / \mathrm{L}$ of $S$. intermedia essential oil with a desirability of 0.9121 , while a concentration of $55.150 \mu \mathrm{L} / \mathrm{L}$ would be sufficient to attain the maximum mortality $(94.72 \%)$ with S. hortensis essential oil with desirability of $0.997 \%$. This indicated that the T. castaneum adults were more susceptible to the essential oil of $S$. hortensis than the S. intermedia (Table 4). 

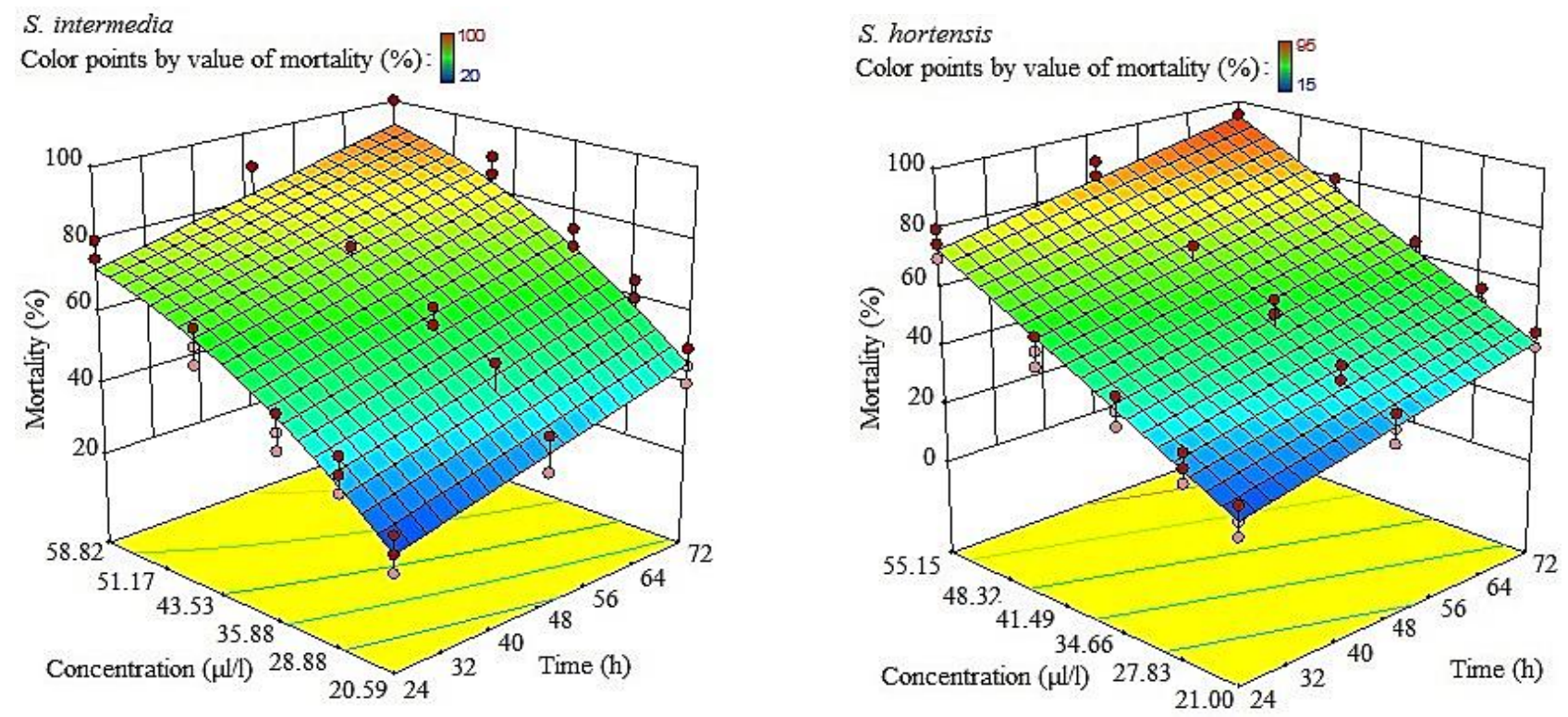

Figure 2. Three-dimensional diagrams of the mortality of T. castaneum caused by the fumigation of $S$. intermedia and $S$. hortensis essential oils.
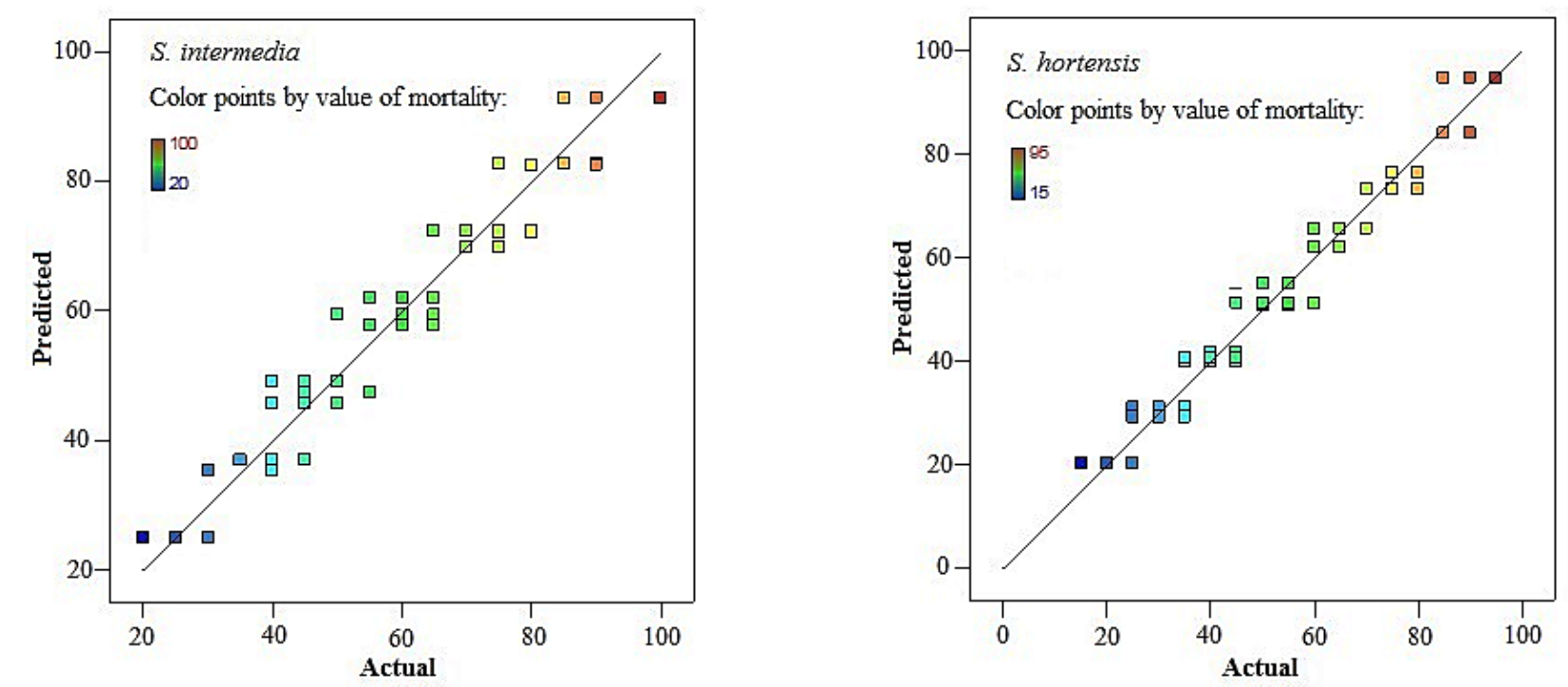

Figure 3. Plots of residual vs. predicted mortality of T. castaneum caused by the fumigation of S. intermedia and S. hortensis essential oils.

Table 4. Optimization of the mortality of T. castaneum caused by the fumigation of S. intermedia and S. hortensis essential oils.

\begin{tabular}{ccccc}
\hline Essential Oil & Mortality (\%) ${ }^{*}$ & Time $(\mathbf{h})$ & Concentration $(\boldsymbol{\mu L} / \mathbf{L})$ & Desirability \\
\hline \multirow{2}{*}{ S. intermedia } & 50.000 & 31.569 & 33.127 & 1.000 \\
& $92.973^{*}$ & 72.000 & 58.820 & 0.912 \\
\hline \multirow{2}{*}{ S. hortensis } & 50.000 & 61.952 & 29.233 & 1.000 \\
& $94.723^{*}$ & 72.000 & 55.150 & 0.997 \\
\hline
\end{tabular}

*The maximum significant mortality percentage based on high desirability, calculated by Design Expert software.

\section{Discussion}

In the S. intermedia essential oil, $95.1 \%$ of the identified compounds were terpenes, in which oxygenated monoterpenoids such as thymol (50.8\%) and carvacrol (11.2\%) had high concentrations. In contrast, the terpenes had only $14.1 \%$ of the total S. hortensis 
essential oil, and this essential oil was rich in benzenoid aromatics such as estragole $(68.0 \%)$, methyl eugenol (5.6\%) and (E)-p-methoxycinnamaldehyde $(4.4 \%)$. Therefore, the essential oils studied in the present study were completely different in terms of chemical components. It was reported that $\gamma$-terpinene (42.3\%), carvacrol (32.8\%), $p$-cymene $(8.1 \%)$, $\beta$-pinene (2.3\%), $\beta$-caryophyllene (2.2\%), $\alpha$-thujene (1.9\%) and $\alpha$-pinene $(1.5 \%)$ were the main components of the essential oil isolated from the aerial parts of $S$. intermedia at the flowering stage from Romania [39]. In the present study, only carvacrol $(0.8 \%)$ and $\alpha$-pinene $(1.3 \%)$ in low concentrations were found in S. hortensis at the pre-flowering stage. In contrast, estragole and methyl eugenol, identified in high amounts in the present study, were not detected in the essential oil investigated by Chambre et al. [39]. The chemical composition of S. intermedia, as one of the Satureja species endemic to Iran, was assessed [40], and $\gamma$-terpinene (37.1\%), thymol (30.2\%), p-cymene (16.2\%), limonene (3.9\%), $\alpha$-terpinene (3.3\%) and $\beta$-myrcene $(2.5 \%)$ were reported as the main components. In the present study, $\gamma$-terpinene, thymol and $p$-cymene were also identified, but there were no traces of limonene, $\alpha$-terpinene or $\beta$-myrcene. Accordingly, differences in the chemical compositions of essential oils may be related to the different species and stages of plants as well as the temperature, humidity, height and other geographical conditions of the cultivation locales $[18,41]$.

The insecticidal effects of the essential oils extracted from S. hortensis and S. intermedia against stored-product insect pests were also reported in some recent studies. The fumigant toxicity of $S$. hortensis essential oil against $C$. maculatus, $S$. zeamais and the Mediterranean flour moth (Ephestia kuehniella Zeller) was studied [22,24,42]. Additionally, the fumigant toxicity of $S$. intermedia essential oils against the lesser grain borer (Rhyzopertha dominica (Fabricius)) and the khapra beetle (Trogoderma granarium Everts) was observed in one of our previous works [43]. These results are consistent with the current findings about the insecticidal potential of essential oils of the S. hortensis and S. intermedia species. Overall, the insecticidal effects of plant essential oils are related to their active compounds such as terpenes and phenylpropanoids [44,45]. As is shown in Table 5, the strong insecticidal effects of the components were identified in high percentages in the S. intermedia and $S$. hortensis essential oils, including 1,8-cineole, carvacrol, estragole, methyl eugenol, $p$-cymene, thymol and $\alpha$-pinene (in both essential oils). The insecticidal activity of $S$. intermedia and $S$. hortensis essential oils may be highly associated with these active compounds.

Table 5. Review of insecticidal effects for the main compounds identified in S. intermedia and S. hortensis essential oils.

\begin{tabular}{|c|c|}
\hline Compound & Reported Insecticidal Effects \\
\hline p-Cymene & $\begin{array}{l}\text { Significant toxicity against the third and fourth instar larvae and pupae of mosquito Culex } \\
\text { quinquefasciatus Say [46]. }\end{array}$ \\
\hline 1,8-Cineole & $\begin{array}{l}\text { High contact toxicity to the third instar larvae of the diamondback moth (Plutella xylostella (L.)), } \\
\text { which was synergistically increased by terpene pulegone [47]. } \\
\text { Significant fumigant toxicity against the adults of rice weevil (Sitophilus oryzae (L.)) and T. } \\
\text { castaneum [48]. }\end{array}$ \\
\hline Thymol & $\begin{array}{l}\text { High contact toxicity to the third instar larvae of the diamondback moth, which was } \\
\text { synergistically increased by the terpene pulegone [47]. } \\
\text { The } 100 \% \text { mortality of adults of } S \text {. granarius by the fumigation of } 163.3 \mu \mathrm{L} / \mathrm{L} \text { after } 96 \mathrm{~h} \text { [49]. }\end{array}$ \\
\hline Carvacrol & $\begin{array}{l}\text { The } 100 \% \text { mortality of adults of } S \text {. granarius by the fumigation of } 166.7 \mu \mathrm{L} / \mathrm{L} \text { after } 96 \mathrm{~h} \text { [49]. } \\
\text { Significant toxicity against the third and fourth instar larvae and pupae of C. quinquefasciatus [46]. } \\
\text { Significant fumigant toxicity against the adults of T. castaneum after } 24 \mathrm{~h} \text { [44]. }\end{array}$ \\
\hline Estragole & $\begin{array}{c}\text { Significant fumigant toxicity and repellent action against the adults of } S \text {. zeamais after } 168 \text { and } 1 \mathrm{~h} \text {, } \\
\text { respectively [45]. }\end{array}$ \\
\hline Methyl eugenol & $\begin{array}{l}\text { Strong fumigant toxicity against S. zeamais [50]. } \\
\text { Toxic to the third instar larvae of cigarette beetle (Lasioderma serricorne (F.)) in the feeding test after } \\
168 \mathrm{~h}[51] .\end{array}$ \\
\hline $\begin{array}{l}\alpha \text {-Pinene (presence in both } \\
\quad \text { essential oils) }\end{array}$ & $\begin{array}{l}\text { The } 100 \% \text { mortality of adults of } S \text {. granarius by the fumigation of } 72.5 \mu \mathrm{L} / \mathrm{L} \text { after } 96 \mathrm{~h} \mathrm{[49]} \text {. } \\
\text { Significant toxicity against the third and fourth instar larvae and pupae of C. quinquefasciatus [46]. }\end{array}$ \\
\hline
\end{tabular}


Furthermore, according to the study of Kim et al. [44], estragole had more fumigant toxicity against $S$. zeamais $\left(\mathrm{LC}_{50}=0.004 \mathrm{mg} / \mathrm{cm}^{3}\right)$ and T. castaneum $\left(\mathrm{LC}_{50}=0.013 \mathrm{mg} / \mathrm{cm}^{3}\right)$ adults than the terpenes limonene, linalool, $\beta$-myrcene, $\alpha$-pinene and $\alpha$-humulene. Therefore, having a high percentage of estragole in $S$. hortensis essential oil can be the main reason for its higher toxicity than $S$. intermedia. However, the synergistic and antagonistic effects between all essential oil components should be considered. For example, the toxicity of 1,8-cineole and thymol against the third instar larvae of diamondback moths (Plutella xylostella (L.)) were synergistically enhanced in combination with another terpene, pulegone, while the pulegone alone had no significant toxicity to the pest [47].

According to our recent studies, the T. castaneum adults were susceptible to the fumigation of S. hortensis and S. intermedia essential oils [43,52]. However, the optimization and modeling of the fumigant toxicity of these essential oils, through RSM, are reported for the first time in the current study. The use of RSM in the optimization and modelling of the insecticidal efficiency of essential oils can be found in a few other investigations. For example, optimization of the fumigant toxicity of Thymus vulgaris L. essential oil indicated that a concentration of $25.86 \mu \mathrm{L} / \mathrm{L}$ and a 59.00-h exposure time were sufficient to achieve $50 \%$ mortality of $R$. dominica adults [53]. In another work on the essential oil of Thymus kotschyanus Boiss. \& Hohen, the optimized condition for $50 \%$ mortality against $R$. dominica adults was $24.62 \mu \mathrm{L} / \mathrm{L}$ and a 57.98-h exposure time [54]. Based on the above-mentioned results, the essential oil of T. kotschyanus was more toxic than the T. vulgaris oil. Regarding the toxicity of $S$. hortensis and S. intermedia essential oils against T. castaneum, 29.23 and $33.13 \mu \mathrm{L} / \mathrm{L}$ of essential oils after 61.95 and $31.57 \mathrm{~h}$, respectively, can result in $50 \%$ mortality of the pest. In one of our other studies, modeling and optimization of the fumigant toxicity of Teucrium polium L. essential oil against T. castaneum adults was evaluated through RSM, and it was found that $97.97 \%$ mortality of the insect pest could be attained by a $20 \mu \mathrm{L} / \mathrm{L}$ essential oil concentration after $72 \mathrm{~h}$ with the model $+0.71-0.047 \mathrm{~A}-8.84 \mathrm{E}-3 \mathrm{~B}+3.89 \mathrm{E}$ $-4 \mathrm{AB}+3.27 \mathrm{E}-3 \mathrm{~A}^{2}+8.38 \mathrm{E}-5 \mathrm{~B}^{2}$ (A and $\mathrm{B}$ are the time and essential oil concentration, respectively) [31]. In comparison with these results, and after $72 \mathrm{~h}$ of exposure time, 55.15 and $58.82 \mu \mathrm{L} / \mathrm{L}$ of $S$. hortensis and S. intermedia essential oils could result in $94.72 \%$ and $92.97 \%$ mortality of $T$. castaneum, respectively. The differences may be associated with different tested essential oils and subjected insect pests. In addition, the above-mentioned and present findings indicated that RSM is a useful method for the optimization and modeling of the insecticidal effects of essential oils.

The disadvantage of such essential oils (i.e., low persistence in environmental conditions) can be improved by micro-and nano-encapsulation formulations based on controlled release techniques $[55,56]$.

\section{Conclusions}

The present study has shown that the essential oils isolated from the aerial parts of S. intermedia and S. hortensis had strong fumigant toxicity against the adults of the red flour beetle T. castaneum. GC-MS analyses indicated that there was a high percentage of insecticidal components such as estragole and methyl eugenol in the S. hortensis essential oil and thymol, carvacrol, $p$-cymene and 1,8-cineole in the S. intermedia essential oil. However, additional studies are required to determine which components have efficient insecticidal activity. Based on RSM, it was found that the best model for the prediction of mortality was linear and the quadratic equation for the essential oil of S. hortensis and S. intermedia, respectively. Up to $94.72 \%$ and $92.97 \%$ mortality of the insect pest, as the maximum significant mortality, can be attained with 55.15 and $58.82 \mu \mathrm{L} / \mathrm{L}$ of $S$. hortensis and $S$. intermedia essential oils, respectively, after $72 \mathrm{~h}$. The essential oils of $S$. hortensis and $S$. intermedia can be proposed for further research in the management of T. castaneum and probably other stored-product insect pests. 
Author Contributions: Conceptualization, A.E. and E.T.; methodology, A.E. and E.T.; software, A.E. and E.T.; formal analysis, E.T. and W.N.S.; investigation, A.E.; writing-original draft preparation, A.E. and E.T.; writing-review and editing, A.E., E.T., W.N.S. and G.C.; funding acquisition, G.C. All authors have read and agreed to the published version of the manuscript.

Funding: This research was funded by the University of Mohaghegh Ardabili (grant number 99/d/9/28635).

Institutional Review Board Statement: Not applicable.

Informed Consent Statement: Not applicable.

Data Availability Statement: All data can be made available upon request to the authors.

Acknowledgments: This research project was supported by the University of Mohaghegh Ardabili in Ardabil, Iran, which is greatly appreciated. W.N.S. participated in this work as part of the activities of the Aromatic Plant Research Center (APRC, https:/ / aromaticplant.org/, accessed on 16 July 2021).

Conflicts of Interest: The authors declare no conflict of interest.

\section{References}

1. Rees, D. Insects of Stored Grain: A Pocket Reference, 2nd ed.; CSIRO Publishing: Collingwood, Australia, 2007 ; pp. 53-56.

2. Granousky, T.A. Stored product pests. In Hand Book of Pest Control, the Behavior, Life History and Control of Household Pests, 1st ed.; Moreland, D., Ed.; Mallis Handbook and Technical Training Co.: Cleveland, OH, USA, 1997; pp. 635-728.

3. Li, J.; Lehmann, S.; Weißbecker, B.; Naharros, I.O.; Schütz, S.; Joop, G.; Wimmer, E.A. Odoriferous defensive stink gland transcriptome to identify novel genes necessary for quinone synthesis in the red flour beetle, Tribolium castaneum. PLoS Genet. 2013, 9, e1003596. [CrossRef]

4. Agarwal, A.; Agashe, D. The red flour beetle Tribolium castaneum: A model for host-microbiome interactions. PLoS ONE 2020, 15, e0239051. [CrossRef] [PubMed]

5. Tuama, S.J.; Ali, S.T.; Hthdy, Z. Effect of Tribolium castaneum in qualitative and quantitative contamination with fungi. Syst. Rev. Pharm. 2020, 11, 1636-1640. [CrossRef]

6. Bosly, H.A.; Kawanna, M.A. Fungi species and red flour beetle in stored wheat flour under Jazan region conditions. Toxicol. Ind. Health 2014, 30, 304-310. [CrossRef] [PubMed]

7. Okoth, S.; De Boevre, M.; Vidal, A.; Di Mavungu, D.J.; Landschoot, S.; Kyallo, M.; Njuguna, J.; Harvey, J.; De Saeger, S. Genetic and toxigenic variability within Aspergillus flavus population isolated from maize in two diverse environments in Kenya. Front. Microbiol. 2018, 9, 57. [CrossRef] [PubMed]

8. Goulson, D. Ecology: Pesticides linked to bird declines. Nature 2014, 511, 295-296. [CrossRef]

9. Reiler, E.; Jørs, E.; Bælum, J.; Huici, O.; Alvarez Caero, M.M.; Cedergreen, N. The influence of tomato processing on residues of organochlorine and organophosphate insecticides and their associated dietary risk. Sci. Total Environ. 2015, 528, 262-269. [CrossRef]

10. Nicolopoulou-Stamati, P.; Maipas, S.; Kotampasi, C.; Stamatis, P.; Hens, L. Chemical pesticides and human health: The urgent need for a new concept in agriculture. Front. Public Health 2016, 4, 148. [CrossRef]

11. Opit, G.P.; Phillips, T.W.; Aikins, M.J.; Hasan, M.M. Phosphine resistance in Tribolium castaneum and Rhyzopertha dominica from stored wheat in Oklahoma. J. Econ. Entomol. 2012, 105, 1107-1114. [CrossRef]

12. Hubhachen, Z.; Jiang, H.; Schlipalius, D.; Park, Y.; Guedes, R.N.C.; Oppert, B.; Opit, G.; Phillips, T.W. A CAPS marker for determination of strong phosphine resistance in Tribolium castaneum from Brazil. J. Pest. Sci. 2020, 93, 127-134. [CrossRef]

13. Wakil, W.; Kavallieratos, N.G.; Usman, M.; Gulzar, S.; El-Shafie, H.A.F. Detection of phosphine resistance in field populations of four key stored-grain insect pests in Pakistan. Insects 2021, 12, 288. [CrossRef]

14. Isman, M.B.; Grieneisen, M.L. Botanical insecticide research: Many publications, limited useful data. Trends Plant Sci. 2014, 19, 140-145. [CrossRef]

15. Basaid, K.; Chebli, B.; Mayad, E.H.; Furze, J.N.; Bouharroud, R.; Krier, F.; Barakate, M.; Paulitz, T. Biological activities of essential oils and lipopeptides applied to control plant pests and diseases: A review. Int. J. Pest. Manag. 2020, 67, 155-177. [CrossRef]

16. Regnault-Roger, C.; Vincent, C.; Arnasson, J.T. Essential oils in insect control: Low-risk products in a high-stakes world. Ann. Rev. Entomol. 2012, 57, 405-425. [CrossRef]

17. Campos, E.V.; Proença, P.L.; Oliveira, J.L.; Bakshi, M.; Abhilash, P.; Fraceto, L.F. Use of botanical insecticides for sustainable agriculture: Future perspectives. Ecol. Indic. 2019, 105, 483-495. [CrossRef]

18. Sefidkon, F.; Jamzad, Z. Chemical composition of the essential oil of three Iranian Satureja species (S. mutica, S. macrantha and S. intermedia). Food Chem. 2005, 91, 1-4. [CrossRef]

19. Tozlu, E.; Cakir, A.; Kordali, S.; Tozlu, G.; Ozer, H.; Akcin, T.A. Chemical compositions and insecticidal effects of essential oils isolated from Achillea gypsicola, Satureja hortensis, Origanum acutidens and Hypericum scabrum against broadbean weevil (Bruchus dentipes). Sci. Hortic. 2011, 130, 9-17. [CrossRef] 
20. Ghorbanpour, M.; Hadian, J.; Hatami, M.; Salehi-Arjomand, H.; Aliahmadi, A. Comparison of chemical compounds and antioxidant and antibacterial properties of various Satureja species growing wild in Iran. J. Med. Plants 2016, 3, 58-72.

21. Taban, A.; Saharkhiz, M.J.; Hooshmandi, M. Insecticidal and repellent activity of three Satureja species against adult red flour beetles, Tribolium castaneum (Coleoptera: Tenebrionidae). Acta Ecol. Sin. 2017, 37, 201-206. [CrossRef]

22. Heydarzade, A.; Moravvej, G.H. Contact toxicity and persistence of essential oils from Foeniculum vulgare, Teucrium polium and Satureja hortensis against Callosobruchus maculatus (Fabricius) (Coleoptera: Bruchidae) adults. Turkish J. Entomol. 2012, 36, 507-518.

23. Yildirim, E.; Krdali, S.; Yazici, G. Insecticidal effects of essential oils of eleven plant species from Lamiaceae on Sitophilus granarius (L.) (Coleoptera: Curculionidae). Rom. Biotechnol. Lett. 2011, 16, 6702-6709.

24. Kordali, S.; Emsen, B.; Yildirim, E. Fumigant toxicity of essential oils from fifteen plant species against Sitophilus zeamais Motschulsky (Coleoptera: Curculionidae). Egypt. J. Biol. Pest Control 2013, 23, 241-246.

25. Riswanto, F.D.O.; Rohman, A.; Pramono, S.; Martono, S. Application of response surface methodology as mathematical and statistical tools in natural product research. J. Appl. Pharm. Sci. 2016, 9, 125-133. [CrossRef]

26. Darvishi, H.; Farhudi, Z.; Behroozi-Khazaei, N. Multi-objective optimization of savory leaves drying in continuous infrared-hot air dryer by response surface methodology and desirability function. Comput. Electron. Agric. 2020, 168, 105112. [CrossRef]

27. Kaur, G.; Kumar, V.; Goyal, A.; Tanwar, B.; Kaur, J. Optimization of nutritional beverage developed from radish, sugarcane and herbal extract using response surface methodology. Nutr. Food Sci. 2018, 48, 733-743. [CrossRef]

28. Kumari, M.; Gupta, S.K. Response surface methodological (RSM) approach for optimizing the removal of trihalomethanes (THMs) and its precursor's by surfactant modified magnetic nanoadsorbents (sMNP)-An endeavor to diminish probable cancer risk. Sci. Rep. 2019, 9, 18339. [CrossRef] [PubMed]

29. Ning, J.; Yue, S. Optimization of preparation conditions of eucalyptus essential oil microcapsules by response surface methodology. J. Food Process. Preserv. 2019, 43, 14188. [CrossRef]

30. Pongsumpun, P.; Iwamoto, S.; Siripatrawan, U. Response surface methodology for optimization of cinnamon essential oil nanoemulsion with improved stability and antifungal activity. Ultras Sonochem. 2020, 60, 104604. [CrossRef] [PubMed]

31. Ebadollahi, A.; Taghinezhad, E. Modeling and optimization of the insecticidal effects of Teucrium polium L. essential oil against red flour beetle (Tribolium castaneum Herbst) using response surface methodology. Inf. Process. Agric. 2020, 7, 286-293. [CrossRef]

32. Ebadollahi, A.; Taghinezhad, E. Modeling of the toxicity of Eucalyptus globulus Labill essential oil against red flour beetle, Tribolium castaneum Herbst. J. Appl. Sci. Environ. Manag. 2020, 24, 2043-2047. [CrossRef]

33. Jamzad, Z. Thymus and Satureja Species of Iran, 1st ed.; Research Institute of Forests and Rangelands: Tehran, Iran, $2009 ;$ pp. $22-31$.

34. Adams, R.P. Identification of Essential Oil Components by Gas. Chromatography/Mass Spectrometry, 4th ed.; Allured Publishing Corporation: Carol Stream, IL, USA, 2007.

35. Mondello, L. FFNSC 3; Shimadzu Scientific Instruments: Columbia, MD, USA, 2016.

36. NIST. NIST17; National Institute of Standards and Technology: Gaithersburg, MD, USA, 2017.

37. Islam, R.; Khan, R.I.; Al-Reza, S.M.; Jeong, Y.T.; Song, C.H.; Khalequzzaman, M. Chemical composition and insecticidal properties of Cinnamomum aromaticum (Nees) essential oil against the stored product beetle Callosobruchus maculatus (F.). J. Sci. Food Agric. 2009, 89, 1241-1246. [CrossRef]

38. Kaveh, M.; Abbaspour-Gilandeh, Y.; Taghinezhad, E.; Witrowa-Rajchert, D.; Nowacka, M. The quality of infrared rotary dried terebinth (Pistacia atlantica L.)-optimization and prediction approach using response surface methodology. Molecules 2021, 26, 1999. [CrossRef] [PubMed]

39. Chambre, D.R.; Moisa, C.; Lupitu, A.; Copolovici, L.; Pop, G.; Copolovici, D.M. Chemical composition, antioxidant capacity, and thermal behavior of Satureja hortensis essential oil. Sci. Rep. 2020, 10, 21322. [CrossRef] [PubMed]

40. Sharifi-Rad, J.; Sharifi-Rad, M.; Hoseini-Alfatemi, S.M.; Iriti, M.; Sharifi-Rad, M.; Sharifi-Rad, M. Composition, cytotoxic and antimicrobial activities of Satureja intermedia C. A. Mey essential oil. Int. J. Mol. Sci. 2015, 16, 17812-17825. [CrossRef]

41. Khalil, N.; El-Jalel, L.; Yousif, M.; Gonaid, M. Altitude impact on the chemical profile and biological activities of Satureja thymbra L. essential oil. BMC Complement. Med. Ther. 2020, 20, 186. [CrossRef]

42. Najafzadeh, R.; Ghasemzadeh, S.; Mirfakhraie, S. Effect of essential oils from Nepeta crispa, Anethum graveolens and Satureja hortensis against the stored-product insect "Ephestia kuehniella (Zeller)". J. Med. Plants By-Prod. 2019, 2, 163-169. [CrossRef]

43. Ebadollahi, A.; Setzer, W.N. Evaluation of the toxicity of Satureja intermedia C. A. Mey essential oil to storage and greenhouse insect pests and a predator ladybird. Foods 2020, 9, 712. [CrossRef]

44. Kim, S.-L.; Lee, D.-W. Toxicity of basil and orange essential oils and their components against two coleopteran stored products insect pests. J. Asia Pac. Entomol. 2014, 17, 13-17. [CrossRef]

45. Rosa, J.S.; Oliveira, L.; Sousa, R.M.O.F.; Escobar, C.B.; Fernandes-Ferreira, M. Bioactivity of some Apiaceae essential oils and their constituents against Sitophilus zeamais (Coleoptera: Curculionidae). Bull. Entomol. Res. 2020, 110, 406-416. [CrossRef]

46. Andrade-Ochoa, S.; Correa-Basurto, J.; Rodríguez-Valdez, L.M.; Sanchez-Torres, L.E.; Nogueda-Torres, B.; Nevarez-Moorillon, G.V. In Vitro and in silico studies of terpenes, terpenoids and related compounds with larvicidal and pupicidal activity against $C u l e x$ quinquefasciatus Say (Diptera: Culicidae). Chem. Cent. J. 2018, 12, 53. [CrossRef]

47. Kumrungsee, N.; Pluempanupat, W.; Koul, O.; Bullangpoti, V. Toxicity of essential oil compounds against diamondback moth, Plutella xylostella, and their impact on detoxification enzyme activities. J. Pest Sci. 2014, 87, 721-729. [CrossRef] 
48. Abdelgaleil, S.A.M.; Mohamed, M.I.E.; Badawy, M.E.I.; El-aramis, S.A.A. Fumigant and contact toxicities of monoterpenes to Sitophilus oryzae (L.) and Tribolium castaneum (Herbst) and their inhibitory effects on acetylcholinesterase activity. J. Chem. Ecol. 2009, 35, 518-525. [CrossRef]

49. Kordali, S.; Usanmaz, A.; Bayrak, N.; Çakır, A. Fumigation of volatile monoterpenes and aromatic compounds against adults of Sitophilus granarius (L.) (Coleoptera: Curculionidae). Rec. Nat. Prod. 2017, 11, 362-373.

50. Wang, C.F.; Yang, K.; Zhang, H.M.; Cao, J.; Fang, R.; Liu, Z.L.; Du, S.S.; Wang, Y.Y.; Deng, Z.W.; Zhou, L. Components and insecticidal activity against the maize weevils of Zanthoxylum schinifolium fruits and leaves. Molecules 2011, 16, 3077-3088. [CrossRef]

51. Imai, T.; Masuda, R. Insecticidal activities of methyleugenol and $\beta$-asarone, from the herbal medicines Saishin and Sekishōkon, and other alkoxy-propenyl-benzene derivatives against the cigarette beetle Lasioderma serricorne (Coleoptera: Anobiidae). Appl. Entomol. Zool. 2017, 52, 183-188. [CrossRef]

52. Ebadollahi, A. Estragole-rich essential oil of summer savory (Satureja hortensis L.) as an eco-friendly alternative to the synthetic insecticides in management of two stored-products insect pests. Acta Agric. Slov. 2020, 115, 307-314. [CrossRef]

53. Ebadollahi, A.; Taghinezhad, E.; Davari, M. Optimization of antifungal and insecticidal effects of garden thyme (Thymus vulgaris L.) essential oil through response surface methodology. Biol. Cont. Pest Plant Dis. 2018, 7, 9-19. [CrossRef]

54. Ebadollahi, A. The essential oil extracted from Thymus kotschyanus Boiss. \& Hohen as a natural substance for management of the lesser grain borer, Rhyzopertha dominica F. Agric. Forest 2018, 64, 490-505. [CrossRef]

55. Nuruzzaman, M.; Rahman, M.M.; Liu, Y.; Naidu, R. Review nanoencapsulation, nano-guard for pesticides: A new window for safe application. J. Agric. Food Chem. 2016, 64, 1447-1483. [CrossRef] [PubMed]

56. Pavoni, L.; Pavela, R.; Cespi, M.; Bonacucina, G.; Maggi, F.; Zeni, V.; Canale, A.; Lucchi, A.; Bruschi, F.; Benelli, G. Green microand nanoemulsions for managing parasites, vectors and pests. Nanomaterials 2019, 9, 1285. [CrossRef] 